\title{
The Relationship Analysis of World Oil Price, Interest Rate, Exchange Rate and Inflation In Indonesia In The Period of 1986 - 2015
}

\author{
Melyana Gita Astika, Hadi Sumarsono, Agus Sumanto \\ Postgraduate, State University of Malang, Indonesia \\ E-mail: melyanagitaastika@gmail.com
}

Received: August 5, 2016; Accepted: December 11, 2016; Published: March 2, 2017

Permalink/DOI: http://dx.doi.org/10.17977/um002v9i12017p012

\begin{abstract}
Indonesia is a developing country that has focused its monetary policy on the stability of the rupiah by putting inflation as the main goal of monetary policy. The purpose of this study was to analyze the long-term, short-term and reciprocity between world oil price, interest rate, exchange rate, and inflation. The type of research is quantitative. The data was collected using techniques of documentation that provided by the Asian Development Bank, the Federal Reserve Bank of St. Louis, World Bank, and Bank Indonesia. The analytical tool that used in this research is test the stationary of data, determining the optimum lag length, Johansen cointegration test, and estimation of Vector Error Correction Model (VECM). Based on estimates VECM can be concluded that: (1) there is a long-term relationship between world oil price, interest rate, exchange rate, and inflation in Indonesia in 1986-2015; (2) there is a short-term relationship between world oil price, interest rate, exchange rate, and inflation in Indonesia in 1986-2015; and (3) there is a reciprocal relationship between the variable interest rate and exchange rate.
\end{abstract}

Keywords: World Oil Price, Interest Rate, Exchange Rate, Inflation JEL Classification: E43, P44

\section{INTRODUCTION}

Indonesia as a developing country has set inflation as a measure of the success of monetary policy that has been implemented. According to Law No. 23, 1999, Bank Indonesia monetary policy focuses on the stability of the rupiah by putting inflation as the ultimate goal of monetary policy. Even in other countries that is even smaller like Namibia (Likuela, 2007; Menji, 2008), inflation is also considered important to be controlled so that stability in the economy of the country could be realized.

Inflation is meant to be a general rise in price levels and occurs continuously. The definition of inflation according to the Central Statistics Agency is the rising prices of goods and services in general in which goods and services are basic needs of society or a decline in purchasing power of a country's currency. Simply put, Bank Indonesia said inflation as rising prices - the prices in general and continuously. The price increase of one or two items alone can not be called inflation unless the increase was widespread (or result in higher prices) on other goods. 
As written in the official website of Bank Indonesia, inflation control is a very important thing because of the high inflation and unstable will give a negative effect on the socioeconomic conditions of society. First, higher inflation would make a real income decline of society so that the standard of living will decline as well. Second, unstable inflation leads to uncertainty for economic players in the decision making in consumption, investment, and production (Retnasih et al., 2016). The uncertainty will ultimately lead to lower economic growth.

Low and stable inflation can create a welfare society. But the achievement is not easy. The stability of inflation can be interrupted in the event of changes in the variables-economic variables that could trigger a rise in general prices. Inflation in Indonesia is not only influenced by the surging demand for goods and services but on the supply side that is associated with disruption of production and distribution. In addition, other inflation disorders can also occur as a result of government policy in determining the price of fuel oil (BBM) and other energy commodities (Bank Indonesia, 2013). Therefore, inflation control is done by the monetary authorities in coordination with the government to implement monetary policy synergized with the other macro policies so that the ultimate goal in controlling the movement of inflation can be achieved.

One of the phenomena of inflation recorded in the history of inflation in Indonesia was in 1980. The surge in world oil prices in 1980 was the effect of the war in Iran - Iraq. In addition, in 1984 inflation had reached $10.4 \%$ due to the devaluation of the rupiah and rising fuel prices as the impact of oil price increases (Bank Indonesia, 1984). But in August 1986 the world oil price decreases causing Indonesia's balance of payments deficit is getting swollen. At that time, Indonesia relies heavily on revenues from oil exports. The Government then pursue policies to devalue the amount of Rp 1,134/US \$ to Rp1.644/US\$ in order to increase export revenues.

In addition to the phenomenon of inflation caused by oil prices, inflation in Indonesia also occurred in 1997. In that year, the turmoil of the Rupiah against the US Dollar (Bank Indonesia, 1997). The impact of exchange rate fluctuations that occurred in 1997 is the increased production costs for manufacturers that use raw materials, intermediates, or the foreign debt burden on the business expansion that has been done. Such conditions trigger a price increase overall goods sold in the country. Especially items made from imported raw materials.

Moreover, the impact of the depreciation of the rupiah is the inability of the company to meet production targets so many companies are reducing costs with layoffs even plant closures. As a result, unemployment increased. This also resulted in investors withdrew their funds because they do not want to run the risk of high losses if invested so that the level of investment decreased. This domino effect shows that the decline of the rupiah as the impact of the global crisis that can weaken the economic fundamentals of Indonesia.

In 1999 the Indonesian economy is getting better. At that time, Bank Indonesia set an inflation target to be achieved as a basis for planning and controlling monetary targets. Based on the experience of previous periods of economic crisis, the general policy direction of the government and Bank Indonesia monetary policy focused on strengthening macroeconomic fundamental, such as in the form of monetary and financial stabilization in order 
to support sustainable economic growth (sustainable). Since 1999 in accordance with Law No. 23 of 1999 concerning Bank Indonesia, Bank Indonesia goal is to achieve and maintain the stability of the Rupiah (Bank Indonesia, 2003). Bank Indonesia also set Inflation Targeting as the ultimate goal of monetary policy. The strategy is paying attention policies pursued by the monetary indicators namely interest rates and exchange rates.

After the economic crisis in 1997, Indonesia re-experiencing the impact of rising world oil prices in 2005 (Handayani, 2010; Samah \& Yati, 2014). Rising world oil prices resulted in subsidized fuel oil (BBM) is increasing. Therefore, the government increased fuel prices on March 1, 2005, with the average increase of $30 \%$, and October 1, 2005, with an increase of $100 \%$. The rising price of fuel oil (BBM) causing the price of goods - staple goods increased (Handayani, 2010). This led to the inflation of $10.5 \%$ and a decrease in purchasing power.

The increase in inflation occurred again in 2007. This is because Indonesia started to feel the impact of global economic conditions experienced a global crisis. In the following year, ie 2008, the impact of the global crisis was compounded by the collapse of the giant world and terminate the employment of employees of large - scale. World oil prices also increased, the rupiah weakened, the number of exports declined due to lower purchasing power of the world at that time. Not to stop there, Indonesia shook by the government's decision to increase fuel prices (BBM) about $28.5 \%$ which resulted in increasing prices and inflation.

According to the Secretariat of the Ministry of the Republic of Indonesia in its official website, the negative impact of the global crisis is the declining performance of the balance of payments, the pressure on the currency and boost the inflation rate amounted to $12.14 \%$ in September 2008. The impact of the global crisis increasingly felt by the weakening of the Rupiah. The rupiah exchange rate fell from USD 10.048/US\$ to US\$ 11.711/US\$ in November 2008. It should, in these conditions theoretically Indonesia benefited as products become cheaper in export destination countries. This condition may increase the number of Indonesian exports. But in reality, it does not happen because other countries also experienced a decline in the exchange rate of its currency. The global crisis led to the purchasing power of the world community, in general, to be decreased.

In addition to the impact on the rupiah exchange rate, the global crisis also had an impact on inflation in Indonesia (Kenward, 2013; Wulan \& Nurfaiza, 2014). This is due to the increase in world oil prices caused the government issued a policy regarding subsidized fuel prices. Higher inflationary pressures fueled by rising world commodity prices, especially oil and food. The price increase impact on the government's policy to increase the price of goods in line with the government's policy in raising the price of subsidized fuel. The government hiked fuel prices by $28.7 \%$ on May 23, 2008, with the following details: a premium price rose Rp. 500,- Rp. 5.500,- to Rp. 6,000,-; diesel prices down from Rp. 4,300,- to Rp. 5,500,-; and kerosene rose from Rp. 2,000 - Rp. 2,500 ,- per liter. The increase in fuel prices caused increase inflation ie from $8.17 \%$ to $11.03 \%$ ie double digits. 
Bank Indonesia has implemented the monetary policy framework of new and consistent with the Inflation Targeting Framework that includes four fundamental elements, namely the use of the BI rate as the operational target, the monetary policymaking anticipatory, communication strategies more transparent, and strengthening policy coordination with the government. Steps - The step is intended to improve the effectiveness and governance of monetary policy in achieving the final goal of price stability to support economic growth in Indonesia.

The fundamental principle on Inflation Targeting framework is that the ultimate objective of monetary policy is simply to achieve and maintain low inflation rate and stable (Bank Indonesia, 2003). In this context, it is assumed that high inflation is a cost to be borne by the economy in the form of low economic growth. In addition, the monetary policy used by controlling the money supply affects real incomes in the short term, as well as to stabilize and decrease the rate of inflation in the long term.

\section{LITERATURE REVIEW Inflation}

Inflation is a monetary phenomenon that shows the increase in the price level in general and occurs continuously. Inflation is a monetary phenomenon caused by excessive monetary growth and unstable (Handayani, 2010). Mankiw (2006) stated inflation Economist use the term to describe a situation in the which the economys overall price level is rising. Therefore we can conclude that inflation is rising prices of goods and services in general in which goods and services are basic needs of society or a decline in purchasing power of a country's currency (Kenward, 2013). There are three criteria that need to be observed for the occurrence of inflation is already rising prices, is common and occurs continuously.

Inflation arises because of the pressure from the demand side (demand pull inflation), from the supply side (cost-push inflation), and from inflation expectations.

1. Demand-pull inflation, inflation caused by high demand for goods and services relative to availability. In the case of this type of inflation, rising prices of goods will usually be followed by an increase in output (real GNP) with the assumption that when the economy has yet to reach fullemployment conditions. Group monetarists consider aggregate demand experienced an increase as a result of the expansion of the amount of money circulating in the community. Meanwhile, according to the category Keynesian aggregate demand rise can be caused by increased consumption, investment, government expenditures, or net exports. Although not an expansion of the money supply.

2. Cost-push inflation, ie inflation due to the shifting aggregate supply curve towards the top left. Factors that cause the aggregate supply curve to shift is the depreciation of the exchange rate, the impact of inflation abroad, especially state - country trading partners, rising prices of factors - factors of production (whether originating from within the country and from abroad) in the market of production factors causing the increase in commodity prices regulated by the government (administered price), and 
going negative supply shocks caused by natural disasters and disruption of distribution. In the case of cost-push inflation price increases often followed by lethargy effort.

3. Inflation expectations are influenced by the behavior of the people and economic players using the inflation rate expectations in the decision of economic activities. The inflation expectations are more likely to be adaptive or forward-looking. This is reflected in the behavior of price formation at the level of producers and traders, especially on the eve of the day - a religious holiday (Eid, Christmas and New Year) and the national minimum wage (UMR). Despite the availability of goods, in general, is estimated to be sufficient in support of the increase in demand, but the price of goods and services at the time - when the religious holidays increase higher than the conditions of supply-demand it. Similarly, when deciding on the minimum wage, traders also increased the price of goods despite the wage increase is not very significant in driving increased demand.

\section{World Oil Price}

The increase in world oil greatly affects the economy of the world, including Indonesia. Some things to note is the increase in world oil prices the direct impact that rising production costs and raises the price of goods - goods, and will eventually lead to inflation of the Cost Push Inflation. The influx of oil prices as one of the macroeconomic variables, which is one form of a supply shock will change the price level and aggregate supply shifts. In general, the aggregate supply function is a function of factors of production. World oil prices is one of the inputs of production. This is because the very fluctuation of oil price movements in the world market so that rising oil prices will necessarily raise the cost of production, and the increase in production will increase prices (Nizar, 2012).

\section{Interest Rate}

According to Nopirin (2000), the interest rate is the cost to be paid by the borrower on the loan is received and is a reward for the lender on their investment. The rate is the central bank's response to the inflationary pressure to remain at the targets. Changes in interest rates do especially if the deviation of the inflation projection to the target (inflation gap) is deemed to have a permanent and consistent with the information and other indicators.

Higher interest rates on the one Handayani (2010), will increase the desire people to save so that the amount of funds banks will increase (Pohan, 2008). The interest rate is also used by the government to control the price level. When a high price level at which the amount of money circulating in the community much so that high public consumption would be anticipated by the government to set interest rates high as well. With high-interest rates expected then is reduced so that the money supply aggregate demand will decrease and the price increase can be overcome.

The interest rate the central bank is important to establish the monetary policy as the central bank can directly affect the interest rate. Open market operations and loan discount rate is a key policy tool the central bank to influence 
the central bank interest rate. Mandatory reserve a third tool, the setting up deposit institutions, and savings institutions to maintain certain obligatory reserves of the banking system deposit as reserves with the central bank.

\section{Exchange Rate}

The exchange rate is the price of one currency into another currency (Mishkin, 2009). The rupiah exchange rate is the ratio of the value or price of the rupiah currency with another currency. Trade between countries in which each country has its own instrument exchange rate requires comparative figures for the value of a currency with other currencies, the so-called foreign exchange rates or exchange rates (Salvatore, 2008). The exchange rate is the dollar value of a country is measured by the value of one unit of the currency against other currencies. If the economic conditions of a country change, it is usually followed by changes in the exchange rate substantial. Problems arise when the currency of a country enter into transactions with other countries, where each country uses a different currency. So the exchange rate is the price that must be paid by a country's currency to acquire another country's currency.

The unchecked exchange rate which fluctuates drastically will cause difficulties in the business community in planning efforts. Especially for those who bring in raw materials from abroad or to sell their goods to export markets. Therefore, the management of the currency relatively stable to one of the monetary factors that support the macro economy (Pohan, 2008).

When a currency's exchange rate rise, the currency appreciation. Conversely, when a currency's exchange rate down then the currency to depreciate. The currency exchange rate is important because it affects domestic prices relative to foreign prices. The price of domestic goods or services in the form of the Rupiah against the price of goods or services in USD is determined by the interaction of two factors, namely the price of domestic goods or services in IDR and the exchange rate of the domestic currency per unit of foreign currency. In general, said that the appreciation of the exchange rate of a country's currency exchange rate against other currencies led to the goods or services of the country concerned is more expensive, and goods or services abroad in the countries concerned are cheaper, with the assumption that the domestic prices of the two countries is constant. Conversely, the depreciation of a country's currency against the currencies of other countries resulted in goods or services abroad cheaper countries concerned, and foreign goods or services in the relevant country more expensive, assuming that domestic prices constant between the two countries.

\section{METHOD}

\section{Data Stationarity Test}

Data stationary test in this study is done by using the Augmented DickeyFuller test (ADF). ADF test is often used to detect whether the data is stationary (no spurious regression) or not stationary. Spurious regression is where the regression results show a significant regression coefficients and R2 are high but not interconnected between variables (Widarjono, 2009). Data are not stationary imbalances often shows the relationship in the short term. Therefore, good data is data that is stationary or not spurious. Time series data in a time series of 
research data will be interconnected. Both are influenced by variables in that year and the year before.

If the data is not stationary at the level, it is necessary to differentiate. Namely a linear combination (unidirectional) of the variable resulting stationary data (Xt - Xt-1). The procedure to determine which data is stationary or not by comparing the value of the ADF statistic with the critical value. ADF statistic value indicated by the t-statistic. If the value of the ADF statistic is greater than the critical value, then the data is stationary. And vice versa. It also can be seen from the value of Prob. Data is stationary if the value of Prob. smaller than $\alpha$.

\section{Determination of Optimum Length Lag}

The impact of an economic policy usually does not directly affect economic activity but take time or inaction (lag) (Tng \& Twek, 2015). While in many cases in economic behavior, the theory is not able to answer how long tardiness. According to Gujarati (2006) when the lag is too little then the residuals of the regression will not show white noise process. So that the model can not accurately estimate the actual error. As a result, the standard error is not estimated properly, but if you put too much would reduce the degrees of freedom.

There are several methods for doing this. One of them is the method of determining the length of inaction using the criteria stated Akaike (Akaike Information Criterion $=$ AIC) and Schwarz (Schwarz Information Criterion = SIC). The length of inaction are selected based on the value of AIC and SIC most minimum by taking the absolute value (Widarjono, 2009).

\section{Cointegration Test}

Time series Data that is not stationary often generate spurious regression. The definition of spurious regression is the case of the coefficient of determination is high enough. This occurs because the relationship is a time series that just shows the trend only. In addition, according to Widarjono (2009), this test can only be done when the data used stationary to the same degree.

Cointegration test that is often used in the study is the Johansen test. This test is performed to determine the relationship between variables in the long run. To view the cointegration relationship between variables, which need to be considered is the value Trace Statistic. If the value of Trace statistic is greater than the critical value then there is cointegration between variables. And vice versa, if the value of Trace statistic is less than the critical value then there is no cointegration between variables. In addition, it can also be seen from the value Probability If the value is smaller than $\alpha$ then there is cointegration between variables. Likewise, if the probability is greater than $\alpha$ then there is no cointegration between variables.

\section{Estimation of Vector Error Correction Model (VECM)}

VECM estimation was performed to identify short-term relationships between variables. According to Engle-Granger in Widarjono (2009), although often not stationary time series data at the current level. According to him, the data are not stationary time series is said to be cointegrated. VECM model is used when the data time series is not stationary at the current level, but the data 
difference stationary and cointegrated so that their theoretical relationships between variables. Given this cointegration, VECM then the model is a model of non-structural VAR or VAR models are teristriksi.

According to Gujarati (2006), method of VAR/VECM a simultaneous equation modeling that has some endogenous variables simultaneously. However, each endogenous variable is explained by the lag or the past of the value of the variable itself and other endogenous variables in the model. According to Sim in Widarjono (2009), in the analysis of VAR/VECM only to note two things: 1) do not need to differentiate which variables endogenous and exogenous, 2) in the analysis of VAR / VECM required number of inactions existing variables to look at the relationship between variable. The models in this study are as follows.

$$
\mathrm{INFt}=\alpha+\beta 1 \mathrm{INFt}-\mathrm{i}+\beta 2 \mathrm{WOPt}-\mathrm{i}+\beta 3 \mathrm{IRt}-\mathrm{i}+\beta 4 \mathrm{ERt}-\mathrm{i}+\mathrm{et}
$$

\begin{tabular}{|c|c|}
\hline \multicolumn{2}{|l|}{ Where : } \\
\hline INFt & $=$ inflation in periode $\mathrm{t}$ \\
\hline INFt-i & $=$ inflation in period $\mathrm{t}-\mathrm{i}$ (lag) \\
\hline WOPt-i & $=$ world oil price period $\mathrm{t}-\mathrm{i}$ (lag) \\
\hline IRt-i & $=$ interest rate in period $\mathrm{t}-\mathrm{i}$ (lag) \\
\hline ERt-I & $=$ exchange rate in period $\mathrm{t}-\mathrm{i}$ (lag) \\
\hline
\end{tabular}

From the regression results are obtained, if the $\mathrm{t}$-count is greater than $\mathrm{t}$ table, then the relationship is significant variables.

\section{Impulse Response Function}

Analysis of Impulse Response is one of the important analytical model VECM. This analysis is used to track the response of the endogenous variables in the VECM system for their shock (shock) or disturbance variable change to other variables in the model (Widarjono, 2009). IRF function describes the shock variable to another variable in the range of a particular period, so it can be seen the length of time it takes a variable in response to the shock of other variables. By using IRF, researchers could track the shock for some period into the future. Akinbobola (2012) stated that the Impulse Response analysis is often done way better and in analyzing the contribution of policies to target other variables in macroeconomic models.

\section{Variance Decomposition}

Besides Impulse Response, more critical analysis in the VECM model is Variance Decomposition. Variance Decomposition is a different method in describing VECM dynamical systems compared with Impulse Response analysis. This analysis illustrates the importance of each variable in the system VECM for their shock (shock). Variance Decomposition is also useful for predicting the contribution in the form of a percentage of each variable due to changes in certain variables in the VECM system. 


\section{Granger Causality Test}

Granger causality test is used to find a causal relationship between endogenous variables in the VECM system. The behavior of economic variables not only have a one-way relationship but showed a two-way connection or causality (Widarjono, 2009). Thus, if there is a causal relationship in the economic behavior in the econometric model are not independent variables for all of the variables is the dependent variable or variables that influence.

The existence of the causal relationship to do with causality test proposed by Granger. This relationship can be seen from the value of Prob. If the value of Prob. smaller than $\alpha$ then there is a causal relationship between variables. Vice versa, if the value of Prob. greater than $\alpha$ then there is no causal relationship between variables

\section{RESULT AND DISCUSSION}

\section{Long-Term Relationships of World Oil Price and Inflation}

The analysis showed that there is a long-term relationship between oil prices and inflation. This can be seen in the test Impulse Response Function and Variance Decomposition. On the test of Impulse Response Function, in the long term is the period of the tenth, shocks on world oil prices responded negatively by inflation that is equal to -1.58 . While the test Variance Decomposition, world oil prices accounted for $11.77 \%$ in inflation. When compared with other variables, the contribution of world oil prices was the biggest in the long-term period. This means, shocks on world oil prices on inflation more so in the longterm period.

Response inflation due to oil price shocks are not in accordance with the existing theory. Where an increase in world oil prices will result in an increase in inflation. For the case in Indonesia during the study period, any increase in world oil prices taken by the government policy of subsidizing fuel. This policy is one way to prevent inflation as a result of the movement of world oil prices. So despite rising world oil prices, inflation in Indonesia is still controllable.

Moreover, rising world oil prices is not accompanied by an increase in inflation due to several things. Bank Indonesia has anticipated increase in oil prices by using monetary policy, namely the interest rate channel. This is done as part of a package of monetary policy in dealing with the impact of inflationary pressures due to rising oil prices. The rate hike by Bank Indonesia as a signal anticipation of risks such as inflation, the current account deficit, and fiscal risks. Thus the real savings and purchasing power will not be eroded, so that will be the foundation for economic growth and poverty reduction rate of more robust future.

Various policies adopted by the government succeeded in reducing inflation. Although the trend of world oil prices have increased, the rate of inflation can be overcome. This shows that there are indeed other factors affecting inflation (interest rate, the rupiah exchange rate, money supply, etc.) so that the results of research in world oil prices negatively affect inflation.

Variance Decomposition test results are consistent with the results of research Handayani (2010) in which world oil prices contributed most to inflation in addition to the contribution of inflation itself. At the beginning of the period, the contribution of oil prices on inflation was not great even the smallest 
compared to other variables. However, in the long term the most influential variable on inflation is the price of oil. It shows that in the long term, oil prices have a major impact on inflation changes in Indonesia.

\section{Long-Term Relationships of Interest Rates and Inflation}

The test result data show that the variable interest rates and inflation have a long-term relationship. The interest rate has a negative relationship patterns against inflation. This can be seen in the test results Impulse Response Function in the long term (the period of the tenth), interest rate shocks responded negatively by inflation of -1.41 . As for the test results Variance Decomposition, interest rates accounted for $10.1 \%$.

The long-term relationship between interest rates and inflation consistent with the theory, where if the interest rate rises, inflation will fall. In this case, Bank Indonesia to control the amount of money circulating in the community so as not to cause inflation by raising interest rates. Rising interest rates, makes people tend to prefer to keep money in the bank so that it can create low inflation. With high-interest rates expected then is reduced so that the money supply aggregate demand will decrease and the price increase can be overcome.

In line with the quantity theory and the monetarist theory that says the inflation caused by the growing amount of money circulating in the community. 1998 inflation in Indonesia reached $58.5 \%$ as at the time the government keeps printing money if it needs more rupees. As a result, the money supply increases that initially totaled 355.6 trillion rupiahs in 1997 to 577.4 trillion rupiah in 1998 . Rising inflation is not only caused by the money supply increases, but added there are other impacts of the weakening rupiah exchange rate at that time. Therefore, Bank Indonesia uses the policy interest rate by $33.9 \%$ to regulate the money supply and ultimately aims to regulate the rate of inflation. As a follow up of the policy of increasing interest rates or tighten monetary policy, Bank Indonesia set SBI interest rate of $16 \%$ in 1998 . The results of these policies is the declining inflation rate of $20.3 \%$ in 1999 and $9.3 \%$ in 2000. The results are consistent with the hypothesis of the study that there is a long-term relationship between interest rates and inflation

The results of this study are consistent with Likukela (2007) that the interest rate effect on inflation in the long term. Where the higher the interest rate, the desire to invest is also smaller. This reason for an entrepreneur will increase investment spending when the expected benefits of the investments greater than the interest rate that he paid for the investment fund which is the cost - the cost of the use of funds (cost of capital). The lower the interest rate, the employer will be compelled to make an investment, because the cost of the use of funds is also smaller. The interest rate in a state of equilibrium (no urge to go up or down) will be achieved when the desire to save the community together with the desire entrepreneurs to make the investment.

\section{Long-Term Relationship Between Exchange Rate and Inflation}

Based on the analysis, there is a long-term relationship the currency and inflation in Indonesia. The interest rate has a pattern of positive relationship to inflation. This can be seen in the test results Impulse Response Function in the long term (the period of the tenth), shocks that occur in the Rupiah exchange rate 
responded positively by inflation of 0.79 . As for the test results Variance Decomposition, the rupiah exchange rate accounted for $6.3 \%$ inflation. Contributions rupiah is the smallest value in comparison with the contributions made by other variables.

The results of the study long-term relationship the currency and inflation is consistent with the existing theory that if the rupiah increased (depreciation) will lead to inflation due to an increase in production costs due to rising prices of imported goods, so the price of domestic goods will rise as well. This shows that the contribution of imports has an important role in some production processes in Indonesia due to raw material shortages in the domestic industry. Therefore, Indonesia is already doing economic openness should guard against external shocks given the rupiah exchange rate is lower than other countries.

Rupiah exchange rate uncertainty affects the process of determining the price of domestic goods in the long term. The rupiah exchange rate weakened (depreciation) will lead to inflation in Indonesia to be increased. Therefore, the results of this study can be concluded that there is a positive relationship between the Rupiah exchange rate with inflation.

This is consistent with results of previous studies that Pardede (2010) which states that in a period of long-term inflation responds positively due to the shock value of the rupiah. In addition, these results are also consistent with the results of research Handayani (2010) that the exchange rate contributed to the inflation in the long term. This shows that the research hypothesis is accepted, that there is a long-term relationship between the currency and inflation.

\section{Short-Term Relationship Between World Oil Prices and Inflation}

Impulse Response Function test results showed that in the short term, oil prices responded negatively to inflation that is equal to -1.34 in the second period. This means that when oil prices rise, inflation will fall. The results of this study do not fit the theory that the positive effect of oil prices on inflation. In addition, based on test results Variance Decomposition, in the short term, the contribution of oil prices on inflation amounted to $1.59 \%$.

Turmoil in world oil prices in the short term not much effect on inflation in Indonesia during the study period. In the short term, the variables that contribute more towards inflation is the rupiah exchange rate and interest rates. Thus, the movement of oil prices may not correspond to the theory, if viewed from the short-term.

This can be seen in 2005 in which there was an increase in world oil prices for 56,65 US\$ / barrel and continued in 2006 for 66,05US\$ / barrel. In 2006, Bank Indonesia raised interest rates up to $11.83 \%$ to tackle inflation is high at $13.1 \%$ due to rising oil prices. Finally, in 2007 the inflation rate back to $6.4 \%$, despite a stable world oil prices actually rose to 72,34 US\$ / barrel. This suggests that the interest rate has more influence on inflation compared with world oil prices. Therefore, these results do not correspond with the theory because there are other factors that affect inflation at the same time.

The results of the study which states that world oil prices have a negative effect on inflation missed where indeed there are other factors that affect inflation more than the world oil prices. Although the study period, the data trend in world oil prices have increased but are not offset by inflation trending stable and did not 
increase following the trend in oil prices. It shows that the effect of subsidizing oil materials is very large at the time of soaring oil prices. Thus, in the short term, inflation can be overcome.

\section{Short-Term Relationship Between Interest Rate and Inflation}

Based on the analysis of Impulse Response Function, in the short term inflation rate responds to shocks in the second period. It can be concluded that the turmoil in the interest rate will not be responded to by the inflation in the first 3 years, but will be responded by inflation at 3 years thereafter (the second). This is a great response -1.58. This suggests that interest rates and inflation have a negative relationship. According to monetarist theory, where the higher the interest rate, then inflation will be lower. In fact, the monetary authorities will raise short-term nominal interest rate at the time of high inflation so that growth in the money supply can be reduced. Bank Indonesia may affect inflation from the demand side, such as investment and private consumption. This is done by setting a policy of interest rate hikes so that public expenditure, the government, and private investment can be limited. The decline in overall demand will eventually be able to reduce inflation in the short term. Therefore, the research hypothesis is accepted.

The monetary policy conducted by Bank Indonesia in regulating the rate of inflation is to use the interest rate instrument which can be seen in 2001. The inflation rate at that time was $12.5 \%$ resulting from the appreciation of the rupiah exchange rate of Rp. 8.422/US\$ to Rp. 10.261/US\$. Overcoming this regard, Bank Indonesia raised interest rates up to $16.22 \%$. This policy is known as a tight monetary policy, in which this step was taken so that the amount of money in circulation is reduced. Decreasing the amount of money in circulation will affect the level of consumption is decreased so that depress the price of goods to a lower level.

The great contribution rate of interest on short-term test Variance Decomposition is shown in line with the results of research Handayani (2010). Interest rates contribute to inflation in the period of the tenth of $2.21 \%$. It is the second largest contribution after the rupiah. In the short term, interest rate setting policy can be used to adjust the rate of inflation to be on target that has been set.

\section{Short-Term Relationship Between Exchange Rate and Inflation}

Results of the test data indicate that there are short-term relationship between the currency and inflation during the study period. This means that the research hypothesis is accepted. Impulse Response Function test results in the short term, the rupiah exchange rate shocks responded positively by inflation of 2.63 in the second period. Variance Decomposition Based on test results, the rupiah exchange rate contributed $6.08 \%$ to inflation. Given the influence of the Rupiah against inflation is the greatest influence. It can be concluded that the increase in the rupiah exchange rate in the short term will lead to a rise in inflation.

During the study period, there have been cases where inflation is caused by weakness of the rupiah. Recorded in 1998 the high inflation is clearly the impact of the depreciation of the rupiah. Prices of domestic goods become expensive so that people's purchasing power is reduced. Although in the short 
term the rupiah may boost inflation, the government can control inflation by controlling interest rates in accordance with the previous description. Given the government can not control the rupiah exchange rate because the exchange rate system adopted is free-floating. Therefore, the government must anticipate the inflation caused by the depreciation of the rupiah with other monetary policy.

If seen from the test results Variance Decomposition, the rupiah does have a huge effect on the short-term period. The great contribution of the Rupiah against inflation was $6.08 \%$. This means that in the short term, inflation is caused more by the shocks of the rupiah compared to world oil prices and interest rates.

\section{Reciprocal Relationship Analysis}

Based on the analysis, there is a two-way relationship is between the interest rate and the exchange rate.

1. The interest rate affects the rupiah exchange rate. Interest rates affect the value of the rupiah exchange rate, as the interest rate determines the number of inquiries for Rupiah. This can be explained by an illustration: if Bank Indonesia raised interest rates (higher than the rate of other countries), then the investor will be invested mainly in the form of Rupiah. Therefore, the number of Rupiah demand increases, the value of the rupiah is appreciated.

2. The rupiah exchange rate affects the interest rate. In contrast to the above, rupiah exchange rate causes Bank Indonesia to conduct monetary policy by setting the interest rate. If the rupiah decreased (depreciation), Bank Indonesia will raise interest rates as a monetary policy reaction. Conversely, if the rupiah appreciates, the Bank Indonesia will lower interest rates.

In any case, monetary policy conducted by Bank Indonesia, in the end, there will be stability in the rupiah. So that the relationship between interest rates and the rupiah have a reciprocal relationship. In which interest rates affect the value of the rupiah, and the rupiah exchange rate affects the interest rate.

\section{CONCLUSION}

Based on the discussion of the analysis results, it can be concluded that there is a relationship between long and short-term global oil prices, interest rates, the rupiah, and inflation in Indonesia in 1986-2015. In addition, there is a reciprocal relationship between the interest rate variable and the value of Rupiah. It shows the interest rate and the rupiah have a close relationship in influencing one another. Given these two variables is a monetary policy tool used by Bank Indonesia to control the rate of inflation in Indonesia.

From these explanations, it is advisable for the government in the implementation of monetary policy in managing inflation rate, they must be supported by other macro policies. Therefore, the formation of inflation expectations in the achievement of the inflation in the short term can be more focused on the long-term targets. Given the influence of the average interest rate is higher than the average of other variables, therefore the government is advised to continue to use interest rates as an instrument or a major variable in maintaining the stability of inflation in Indonesia. In addition, further researchers are expected to further explore factors that affect inflation. In spite of some fact 
or event in the field that shows the influence of a variable on inflation. Therefore, further researchers are highly expected to incorporate other variables that have more influence on inflation in accordance with the existing theory.

\section{REFERENCES}

Akinbobola. (2012). The Dynamics of Money Supply, Exchange Rate and Inflation in Nigeria. Journal of Applied Finance \& Banking, 2(4), 117141.

Bank Indonesia. (1984). Sejarah Bank Indonesia: Moneter Periode 1983-1997. retieved from http://www.bi.go.id/id/tentang-bi/museum/sejarah-bi/bi/ Documents/3ee69417b88f49638fa703d1c11f4f4bSejarahMoneterPeriode 19831997.pdf.

Bank Indonesia. (1997). Sejarah Bank Indonesia: Moneter Periode 1997-1999. http://www.bi.go.id/id/tentang-bi/museum/sejarah-bi/bi/Documents/f0c4c dd061e4493fafe0cadf16ec4235SejarahMoneterPeriode19971999.pdf.

Bank Indonesia. (2003). Bank Sentral Republik Indonesia Tinjauan Kelembagaan, Kebijakan dan Organisasi. Jakarta: Pusat Pendidikan dan Studi Kebanksentralan (PPSK).

Bank Indonesia. (2013). Tinjauan Kebijakan Moneter. Retrieved from http://www.bi.go.id/id/publikasi/kebijakan-moneter/tinjauan/Default.aspx

Firdaus, M. (2011). Aplikasi Ekonometrika Untuk Data Panel Dan Time Series. Bogor: IPB Press.

Gujarati, D. R. (2006). Dasar - dasar Ekonometrika Jilid 1. Jakarta: Erlangga.

Handayani, R. (2010). Analisis Inflasi dan Variabel Makro Ekonomi di Indonesia. (repository.usu.ac.id/handle/123456789/27583, accesed on 6 January 2016). Medan: Sekolah Pasca Sarjana, Universitas Sumatera Utara.

Kementrian Sekretariat Negara Republik Indonesia. Perekonomian Indonesia Tahun 2008 Tengah Krisis Keuangan Global. Retrieved from http://www.setneg.go.id/index.php?option=com_content\&tast=view\&id= 3698.

Kenward, L. R. (2013). Inflation Targeting in Indonesia, 1999-2012: an ex Post Review. Bulletin of Indonesian Economic Studies, 49(3), 305-327.

Likukela, M. (2007). An Econometrics Analysis of The Determinants of Inflation in Namibia. Retrieved from http://wwwisis.unam.na/theses/likukela2007. Pdf.

Mankiw, G. N. (2006). Principle of Economics, Pengantar Ekonomi Makro Edisi Ketiga. Alih Bahasa oleh Chriswan Sungkono. Jakarta: Salemba Empat.

Menji, S. (2008). Determinants of Recent Inflation in Ethiopia. Munich Personal RePEc Archive, 4 (29668), 1-57.

Mishkin, F. S. (2009). Ekonomi Uang, Perbankan, dan Pasar Keuangan Buku 2 Edisi 8. Jakarta: Salemba Empat.

Nizar, M. A. (2012). Dampak Fluktuasi Harga Minyak Dunia Terhadap Perekonomian Indonesia. Buletin Ilmiah Litbang Perdagangan, 6(2), 189210.

Nopirin. (2000). Ekonomi Moneter. Yogyakarta: BPFE. 
Pardede, A. (2010). Analisis Respon Variabel Ekonomi Makro Terhadap Inflation Targeting Framework di Indonesia. Retrieved from repository.usu.ac.id/ handle/123456789/21848.

Pohan, A. (2008). Potret Kebijakan Moneter Indonesia. Jakarta: Raja Grafindo Persada.

Retnasih, N. R., Agustin, G., \& Wulandari, D. (2016). Analisis Guncangan Eksternal terhadap Indikator Moneter dan Makroekonomi Indonesia. Jurnal Ekonomi dan Studi Pembangunan, 8(2), 101-113.

Salvatore, D. (2008). Theory and Problem of Micro Economic Theory 3th Edition. Alih Bahasa oleh Rudi Sitompul. Jakarta: Erlangga.

Samah, A. E., \& Yati, N. (2014). Kinerja Perekonomian Indonesia dengan Kenaikan Harga Minyak Mentah Dunia. Buletin Ilmiah Litbang Perdagangan, 70-92.

Tng, B. H., \& Kwek, K. T. (2015). Financial Stress, Economic Activity and Monetary Policy in the ASEAN 5-Economies. Applied Economics, 47:48, 5169-5185. http://dx.doi.org/10.1080/00036846.2015.1044646

Widarjono, A. (2009). Ekonometrika. Yogyakarta: Ekonisia.

Wulan, E. R., \& Nurfaiza, S. (2014). Analysis of Factors Affecting Inflation in Indonesia: An Islamic Perspectives. International Journal of Nusantara Islam, 2(2), 67-80. 